\title{
Impact of ice sheet meltwater fluxes on the climate evolution at the onset of the Last Interglacial
}

\author{
Heiko Goelzer ${ }^{1, a}$, Philippe Huybrechts ${ }^{1}$, Marie-France Loutre ${ }^{2}$, and Thierry Fichefet ${ }^{2}$ \\ ${ }^{1}$ Earth System Sciences \& Departement Geografie, Vrije Universiteit Brussel, Brussels, Belgium \\ ${ }^{2}$ Université catholique de Louvain, Earth and Life Institute, Georges Lemaître Centre for Earth and Climate \\ Research (TECLIM), Louvain-la-Neuve, Belgium \\ ${ }^{a}$ now at: Institute for Marine and Atmospheric Research Utrecht, Utrecht University, the Netherlands \\ Correspondence to: Heiko Goelzer (h.goelzer@uu.nl, heiko.goelzer@vub.ac.be)
}

Received: 21 August 2015 - Published in Clim. Past Discuss.: 17 September 2015

Revised: 30 June 2016 - Accepted: 12 July 2016 - Published: 25 August 2016

\begin{abstract}
Large climate perturbations occurred during the transition between the penultimate glacial period and the Last Interglacial (Termination II), when the ice sheets retreated from their glacial configuration. Here we investigate the impact of ice sheet changes and associated freshwater fluxes on the climate evolution at the onset of the Last Interglacial. The period from 135 to $120 \mathrm{kyr} \mathrm{BP}$ is simulated with the Earth system model of intermediate complexity LOVECLIM v.1.3 with prescribed evolution of the Antarctic ice sheet, the Greenland ice sheet, and the other Northern Hemisphere ice sheets. Variations in meltwater fluxes from the Northern Hemisphere ice sheets lead to North Atlantic temperature changes and modifications of the strength of the Atlantic meridional overturning circulation. By means of the interhemispheric see-saw effect, variations in the Atlantic meridional overturning circulation also give rise to temperature changes in the Southern Hemisphere, which are additionally modulated by the direct impact of Antarctic meltwater fluxes into the Southern Ocean. Freshwater fluxes from the melting Antarctic ice sheet lead to a millennial timescale oceanic cold event in the Southern Ocean with expanded sea ice as evidenced in some ocean sediment cores, which may be used to constrain the timing of ice sheet retreat.
\end{abstract}

\section{Introduction}

Understanding the climate and ice sheet evolution during past warm periods in the history of the Earth may provide important insights for projections of future climate and sea-level changes. The growing number of palaeoreconstructions for the Last Interglacial period (e.g. Govin et al., 2012; Capron et al., 2014) in combination with improved model simulations of this most recent warm period (e.g. Bakker et al., 2013; Lunt et al., 2013; Langebroek and Nisancioglu, 2014; Loutre et al., 2014) makes it an interesting target for studying the coupled climate-ice sheet system.

According to reconstructions, the Last Interglacial (LIG, from $\sim 130$ to $115 \mathrm{kyr} \mathrm{BP}$ ) was characterised by a global annual mean surface temperature of up to $2{ }^{\circ} \mathrm{C}$ above the preindustrial era (e.g. Turney and Jones, 2010; Capron et al., 2014) and a sea-level high stand of 6-9 $\mathrm{m}$ above the present day (Kopp et al., 2009; Dutton and Lambeck, 2012). As the penultimate glacial maximum was at least as severe as the Last Glacial Maximum (LGM) in both hemispheres (EPICA community members, 2004; Svendsen et al., 2004), this implies a large amplitude glacial-interglacial transition in terms of temperature and ice sheet configuration. At the onset of the LIG, a rapid warming of $\sim 10^{\circ} \mathrm{C}$ from the preceding cold state is recorded in deep Antarctic ice cores (MassonDelmotte et al., 2011) to have occurred between $\sim 135$ and $130 \mathrm{kyr}$ BP. Current ice core records from the Greenland ice sheet (GrIS) do not extend long enough back in time to cover the entire penultimate deglaciation and associated warming (NEEM community members, 2013), but a similar timing and magnitude of warming compared to the Antarctic can be reconstructed for sea surface temperatures off the western European margin (Sánchez Goñi et al., 2012). The warming is closely related to an ice sheet retreat in both hemispheres. Despite large uncertainties in reconstructions, the global sea- 


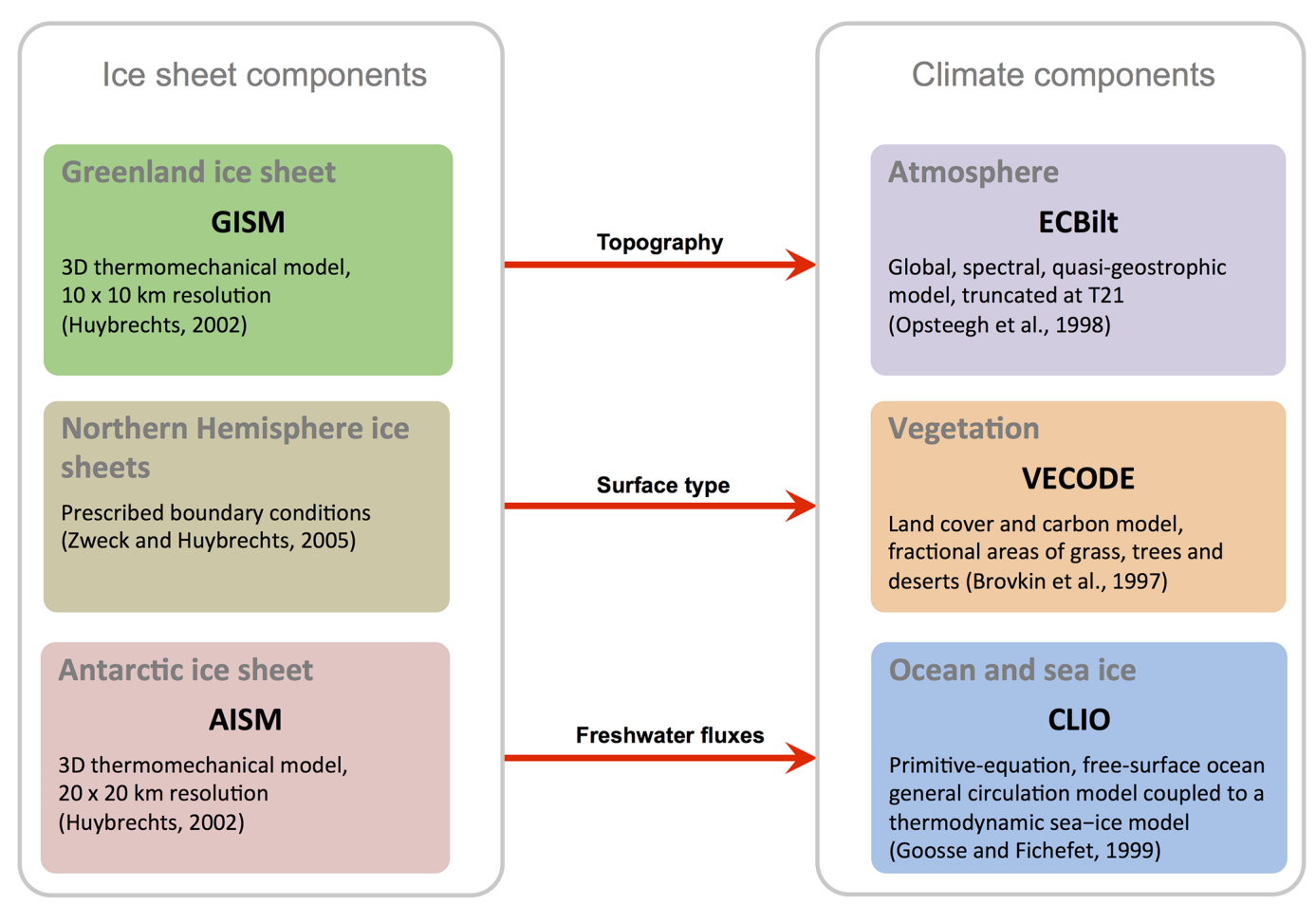

Figure 1. LOVECLIM model setup for the present study including prescribed ice sheet boundary conditions from the Northern Hemisphere, Greenland, and Antarctic ice sheets.

level stand at $135 \mathrm{kyr} B \mathrm{P}$ of as low as $-80 \mathrm{~m}$ (Grant et al., 2012) is indicative of the large amount of freshwater that entered the ocean in the form of meltwater from the retreating ice sheets during Termination II. Aside from determining the amplitude of sea-level changes, which is the focus of many studies (e.g. Robinson et al., 2011; Stone et al., 2013), the associated climate impacts and possible feedbacks on the ice sheet evolution of this freshwater forcing are an important element for a process understanding of the coupled climate-ice sheet changes at that time.

A climatic mechanism that is thought to be directly related to changes in the NH ice sheet freshwater fluxes (FWFs) is the interhemispheric see-saw effect (Stocker, 1998) that links SH warming to a weakening of the Atlantic meridional overturning circulation (AMOC). If the see-saw effect was active during the onset of the LIG, NH ice sheet melting during Termination II would have been the cause of a substantial AMOC weakening and NH cooling, while reduced interhemispheric heat transport would have caused a gradual SH warming (Stocker and Johnson, 2003). The see-saw mechanism was evoked to explain part of the peak Antarctic warming during the LIG (e.g. Holden et al., 2010; Marino et al., 2015), even though some Southern Ocean (SO) warming was shown by Langebroek and Nisancioglu (2014) to be possible with orbital forcing alone (without $\mathrm{NH}$ freshwater forcing). The see-saw mechanism has been speculated to have caused increased Antarctic ice shelf melting and West Antarctic ice sheet (WAIS) retreat (Duplessy et al., 2007). The retreat of the WAIS, which is believed to have been grounded at the edge of the continental shelf during the penultimate glaciation, generated a large anomalous flux of freshwater into the SO. Such freshwater forcing could have had a substantial influence on the SO configuration in terms of sea ice extent and ocean circulation as shown in model experiments for the last deglaciation (Menviel et al., 2011), for future global warming scenarios (Swingedouw et al., 2008), and for the present day (Bintanja et al., 2013). The impact of increased Antarctic FWFs is thought to consist of a surface ocean freshening, stratification of the surface ocean, and cooling, in turn promoting sea ice growth (e.g. Bintanja et al., 2013) and reduced Antarctic Bottom Water (AABW) formation (Menviel et al., 2011). Recently, Golledge et al. (2014) suggested that such a mechanism might also have provided a feedback on Antarctic ice sheet (AIS) retreat for meltwater pulse 1A during the last glacial-interglacial transition (Termination I), by promoting warming of mid-depth ocean waters that provide additional heat for melting ice shelves.

In the present work, we study the effect of evolving ice sheet boundary conditions on the climate by simulating the climate evolution at the onset and over the course of the LIG with an Earth system model of intermediate complexity (EMIC). The model is forced with realistic ice sheet boundary conditions from offline simulations of ice dynamic models of the AIS and GrIS and reconstructions of the other NH 
ice sheets. With this study we extend the work of Loutre et al. (2014) by additionally including dynamic ice sheet changes of the GrIS and AIS and focusing on the effect of ice sheet freshwater fluxes on the climate, particularly in the Southern Hemisphere (SH). The model and experimental setup are described in Sects. 2 and 3, respectively, followed by results (Sects. 4, 5, and 6), their discussion (Sect. 7), and conclusions (Sect. 8).

\section{Model description}

We use the EMIC LOVECLIM version 1.3, which includes components representing the atmosphere, the ocean and sea ice, the terrestrial biosphere, and the ice sheets (see Fig. 1). The model has been utilised in a large number of coupled climate-ice sheet studies (e.g. Driesschaert et al., 2007; Swingedouw et al., 2008; Goelzer et al., 2011, 2012a; Loutre et al., 2014) and is described in detail in Goosse et al. (2010).

In this study, the climate components are forced by timeevolving ice sheet boundary conditions, which are calculated offline, i.e. uncoupled from the climate evolution. Our modelling approach for the ice sheets consists of a combination of reconstructed $\mathrm{NH}$ ice sheets (except the GrIS) based on geomorphological data (Sect. 2.1) and of stand-alone ice dynamic simulations of the GrIS and AIS (Sect. 2.2). In either case, the boundary conditions provide time-evolving topography, ice sheet extent (albedo), and spatially and temporally variable FWFs to the climate model. We conserve global salinity and global volume in the ocean model to avoid numerical problems, a common practice for simulations with large amounts of freshwater input.

\subsection{Northern Hemisphere ice sheet forcing}

We have little geomorphological evidence for Northern Hemisphere (NH) ice sheet evolution during Termination II since it was mostly destroyed by the re-advance leading to the LGM. Therefore, the reconstruction of NH ice sheet evolution for the period of interest is made based on information from the last deglaciation. The method has already been described in some detail in Loutre et al. (2014). Nevertheless, we include a more thorough description here (Appendix A). The resulting boundary conditions used to force the climate model consist of a chronology of ice mask and surface elevation changes (Fig. 2) and freshwater fluxes (Fig. 3b) over the entire LIG period. Support for the derived chronology of $\mathrm{NH}$ ice sheet evolution and their FWFs can be found in records of ice-rafted detritus (IRD) from the subpolar North Atlantic (Kandiano et al., 2004; Oppo et al., 2006). These records show variability of similar signature during the deglaciation and in particular a last IRD peak at $\sim 128 \mathrm{kyr} \mathrm{BP}$ preceding low IRD levels throughout the LIG.

\subsection{Simulations of the Greenland and Antarctic ice sheets}

For the present study, the climate components are partially forced by results from stand-alone simulations of the GrIS and AIS, which have been adapted from existing ice sheet model experiments (Huybrechts, 2002). The configuration of both ice sheet models and the forcing interface follows the description in Goosse et al. (2010) with the following exceptions. Forcing for the ice sheet models is derived from scaling present-day observations of temperature and precipitation with indices based on ice core records, as often done for long-term palaeo-ice-sheet modelling (e.g. Huybrechts, 1990; Letréguilly et al., 1991; Zweck and Huybrechts, 2005; Greve et al., 2011). For the GrIS the forcing record was created following Fürst et al. (2015). We combine a synthesised Greenland $\delta^{18} \mathrm{O}$ record derived from Antarctica Dome C using a bipolar seesaw model (Barker et al., 2011) with the NEEM temperature reconstruction (NEEM community members, 2013) between 128.44 and $120 \mathrm{kyr}$ BP. The Barker $\delta^{18} \mathrm{O}$ record is converted to a spatially uniform temperature anomaly with a constant temperature/isotope factor $\Delta T=2.4^{\circ} \mathrm{C} / \%_{0} \times\left(\delta^{18} \mathrm{O}+34.83\right)$ as in Huybrechts (2002). Positive temperature anomalies of the NEEM record are scaled by a factor 0.6 to fulfil constraints on maximal ice sheet retreat from Camp Century and Dye 3 ice core locations that are assumed to have been ice-covered during the LIG. This places the GrIS evolution in the range of former model estimates during that period (e.g. Robinson et al., 2011; Born and Nisancioglu, 2012; Stone et al., 2013). Such scaling is in line with recent studies (e.g. van de Berg et al., 2013; Merz et al., 2014; Sjolte and Hoffmann, 2014; Steen-Larsen et al., 2014) that put in question the high temperature of the central estimate reconstructed from the NEEM record. Precipitation rates for ice sheet forcing vary percentage-wise as a function of the $\delta^{18} \mathrm{O}$ record.

The AIS forcing is derived directly from the Antarctica Dome C record (EPICA community members, 2004), following again procedures described by Huybrechts (2002). Here precipitation changes are assumed proportional to the saturated water vapour pressure gradient relative to the temperature above the surface inversion layer. Furthermore, both ice sheet models are forced by changes in global sea-level stand based on the benthic deep-sea record of Lisiecki and Raymo (2005) for the GrIS and on a more recent sea-level reconstruction using Red Sea data (Grant et al., 2012) for the AIS, where the sea-level changes are the dominant forcing. The chronology of the Red Sea record is expected to be more accurate since new dating techniques are applied (Grant et al., 2012). The impact of using another sea-level record for the GrIS simulation over the LIG is small, because of the largely land-based character of the ice sheet during that period. The AIS model is run at a horizontal resolution of $20 \mathrm{~km} \times 20 \mathrm{~km}$ instead of $10 \mathrm{~km} \times 10 \mathrm{~km}$ (as in the standard LOVECLIM configuration and for the GrIS model) due to 


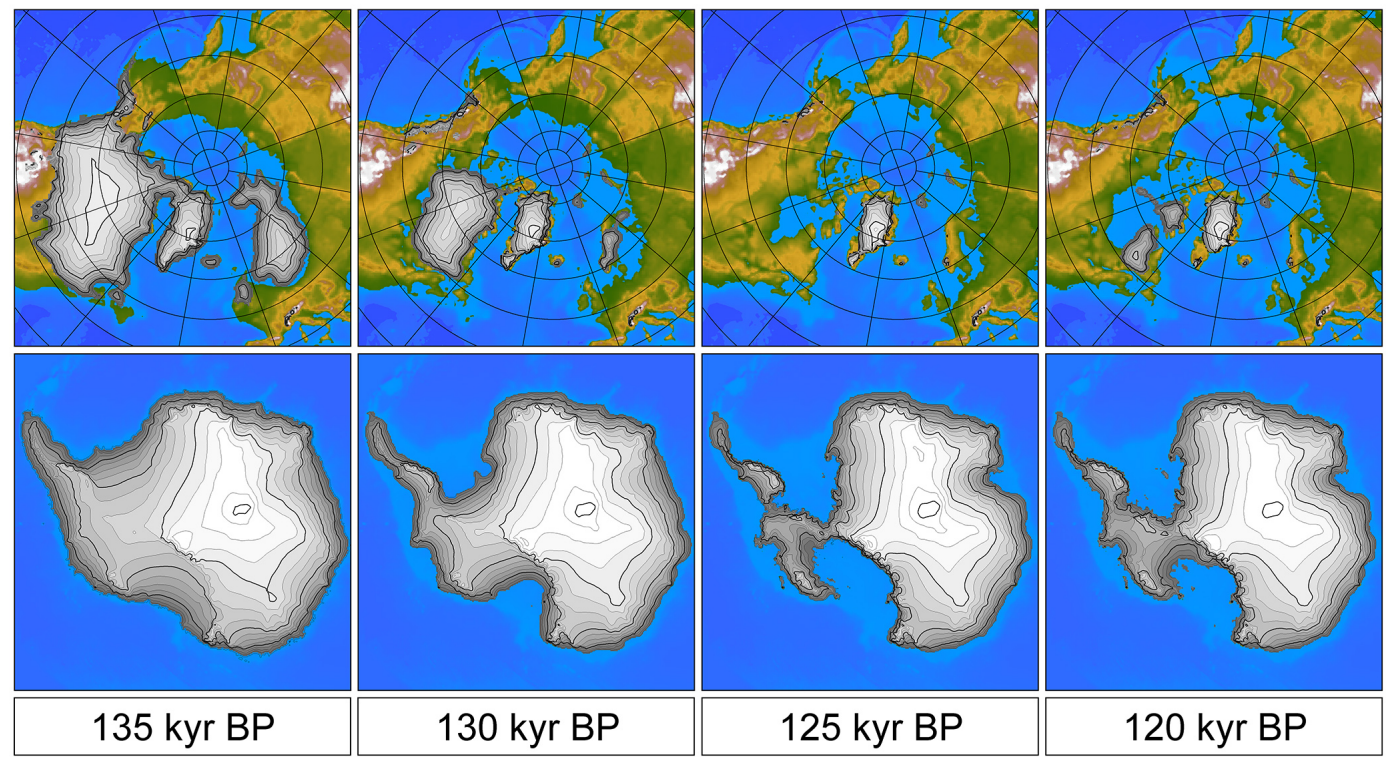

Figure 2. Evolution of reconstructed Northern Hemisphere ice sheets and embedded modelled GrIS (top) and modelled AIS (bottom) used as boundary conditions for the climate model.

computational constraints for the relatively long duration of the LIG simulation.

To embed the dynamic GrIS simulation in the other $\mathrm{NH}$ boundary conditions, the geometric evolution of the GrIS overrides prescribed changes where Greenland ice is present. Therefore, the prescribed ice sheet evolution and associated FWFs are not limited by the present-day configuration of the GrIS as in Loutre et al. (2014). The ice sheet evolution is illustrated in Fig. 2 for the modelled GrIS embedded in the NH reconstruction (top) and for the modelled AIS (bottom). Ice volume evolution for the $\mathrm{NH}$ ice sheets and the GrIS and AIS is given in Fig. 3a and c, respectively. The FWFs from the dynamic GrIS and AIS (Fig. 3d) replace the background freshwater flux from runoff over land calculated by the land model.

In our setup, the combined sea-level contributions from Antarctica and the NH (including Greenland) fall within the $67 \%$ confidence interval of probabilistic sea-level reconstructions (Kopp et al., 2009) for the first peak in sea-level contributions and the following period ( $124-120 \mathrm{kyr} \mathrm{BP})$. For both hemispheres, the final $20 \mathrm{~m}$ rise in sea level at the onset of the LIG is, however, steeper and occurs 1-2 kyr earlier as compared to the reconstructions. When assuming a maximum contribution from glaciers $(0.42 \pm 0.11)$ and an additional estimate for thermal expansion of the ocean $(0.4 \pm 0.3)$ as given by Masson-Delmotte et al. (2013), the assumed ice sheet evolution in our setup reproduces well the average sea-level contribution between 125 and $120 \mathrm{kyr} \mathrm{BP}$ from the best estimate of Kopp et al. (2009), but it does not represent the multi-peak structure of global sea-level contribution during the LIG as suggested by Kopp et al. (2009, 2013). More details about the ice sheet and sea-level evolu- tion can be found in a companion paper (Goelzer et al., 2016) that specifically deals with the sea-level contribution of the ice sheets during the LIG in a fully coupled model setup.

\subsection{Initialisation}

The goal of our initialisation technique is to prepare a climate model state for the transient simulations starting at $135 \mathrm{kyr}$ BP that exhibits a minimal coupling drift. Both the GrIS and AIS models are integrated over the preceding glacial cycles and the entire LIG in stand-alone mode. The climate model is then initialised to a steady state with ice sheet boundary conditions, greenhouse gas (GHG) forcing, and orbital parameters for the time of coupling ( $135 \mathrm{kyr}$ BP). In this way, when LOVECLIM is integrated forward in time for transient experiments, the climate component is already relaxed to the ice sheet boundary conditions and exhibits a minimal model drift in unforced control experiments (not shown).

\section{Experimental setup}

All simulations are forced by time-dependent changes in GHG concentrations and insolation running from 135 until $120 \mathrm{kyr}$ BP (Fig. 4). The radiative forcing associated with the reconstructed GHG levels (Petit et al., 1999; Peìpin et al., 2001; Raynaud et al., 2005; Loulergue et al., 2008; Spahni et al., 2005) is below pre-industrial values for most of this period and barely exceeds it at $\sim 128 \mathrm{kyr} B$. The changes in the distribution of insolation received by the Earth are dynamically computed from the changes in the orbital configuration (Berger, 1978) and represent the governing $\mathrm{NH}$ 
Table 1. Matrix of all experiments and the respective ice sheet components that evolve in time (yes) or are fixed (no). In the latter case, freshwater fluxes (FWF, bold) are kept constant and topography and surface albedo are fixed to the pre-industrial configuration.

\begin{tabular}{lllllll}
\hline EXP & topo NH & FWF NH & topo GrIS & FWF GrIS & topo AIS & FWF AIS \\
\hline Reference & yes & yes & yes & yes & yes & yes \\
noGfwf & yes & yes & yes & no & yes & yes \\
noAGfwf & yes & yes & yes & no & yes & no \\
noAG & yes & yes & no & no & no & no \\
noIS & no & no & no & no & no & no \\
\hline
\end{tabular}
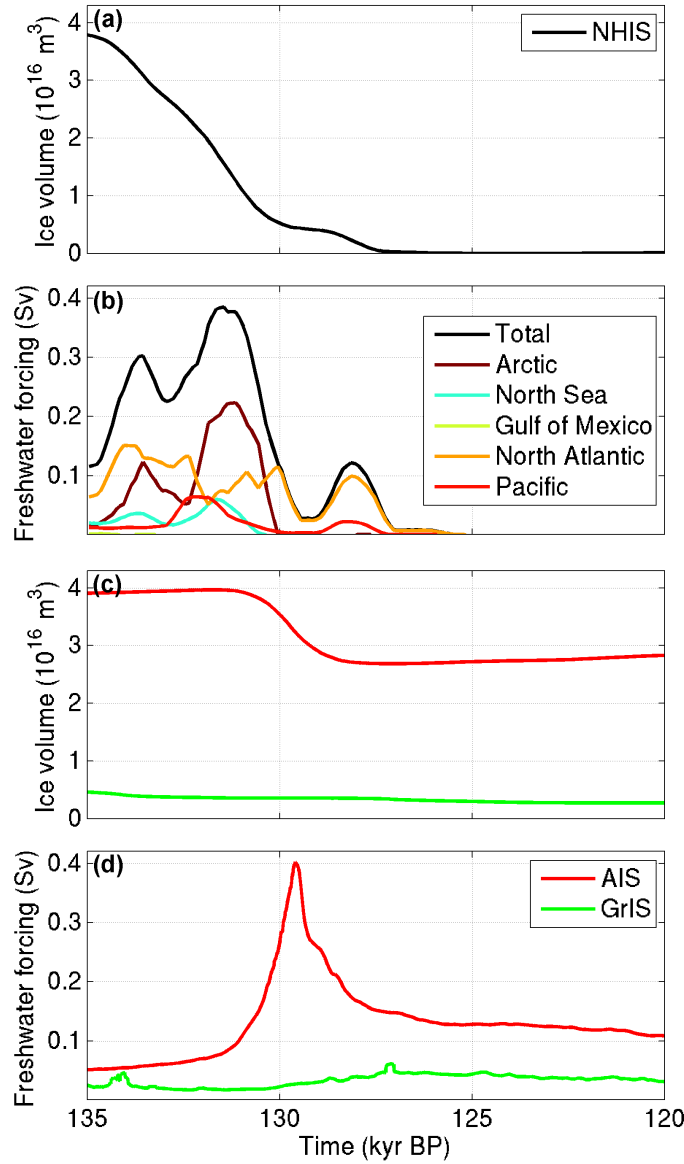

Figure 3. Reconstructed ice volume (a, c) and freshwater forcing (b, d) from the NH ice sheets (a, b) and from the GrIS and AIS (c, d). See Goelzer et al. (2012b) for definition of oceanic basins in (b).

forcing during peak LIG conditions aside from evolving ice sheet boundary conditions. In the following, we will compare results of the reference experiment with all ice sheet boundary conditions evolving in time (Reference) to experiments in which the ice sheet boundary conditions are partially fixed to the pre-industrial configuration (Table 1). To disentangle the effects of the individual ice sheets, the experiments noGfwf (suppressed GrIS freshwater fluxes) and noAGfwf (suppressed FWFs from both AIS and GrIS) are complemented by two predecessor experiments with fixed
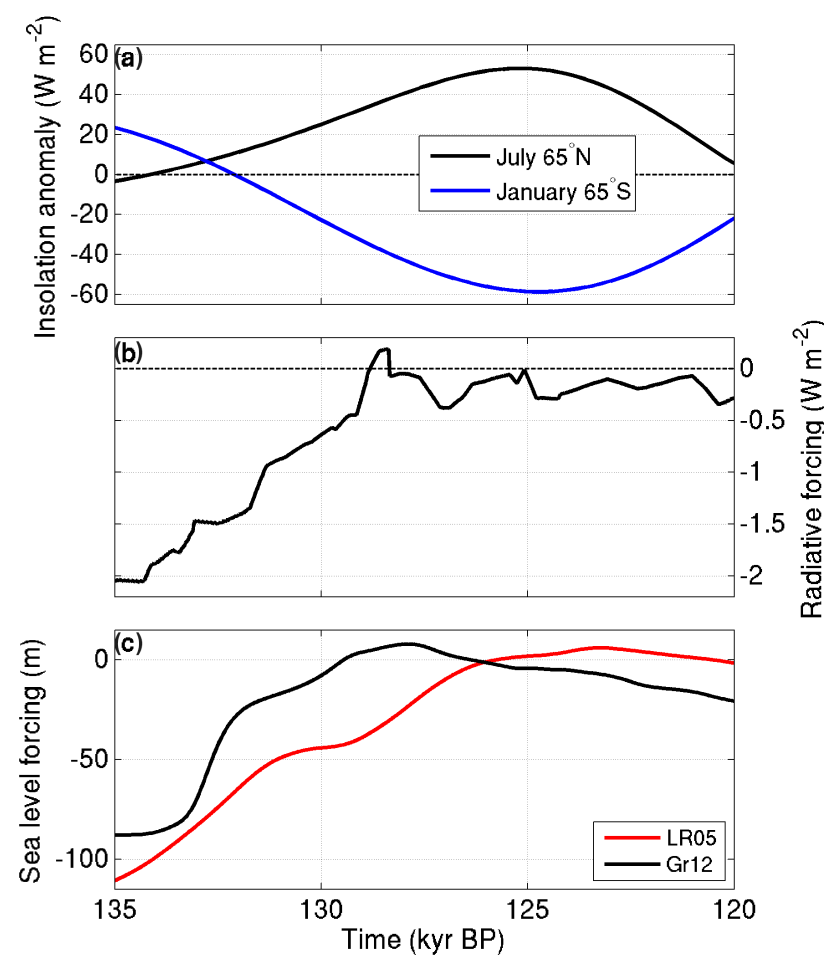

Figure 4. Prescribed model forcings. (a) Average monthly insolation anomaly relative to the pre-industrial era at $65^{\circ} \mathrm{N}$ in July (black) and $65^{\circ} \mathrm{S}$ in January (blue). (b) Combined radiative forcing anomaly of prescribed greenhouse gas concentrations $\left(\mathrm{CO}_{2}\right.$, $\mathrm{CH}_{4}, \mathrm{~N}_{2} \mathrm{O}$ ) relative to the pre-industrial era. (c) Sea-level forcing for the ice sheet components derived from either oceanic $\delta^{18} \mathrm{O}$ data (Lisiecki and Raymo, 2005, red) scaled to a global sea-level contrast between LGM and present day of $130 \mathrm{~m}$ or from a Red Sea relative sea-level record (Grant et al., 2012, black).

AIS and GrIS and evolving NH boundary conditions (noAG), as well as a climate experiment forced by insolation and GHG changes only with all ice sheet boundary conditions fixed (noIS). The last two experiments correspond to the allLR and IGonly experiments from Loutre et al. (2014). 


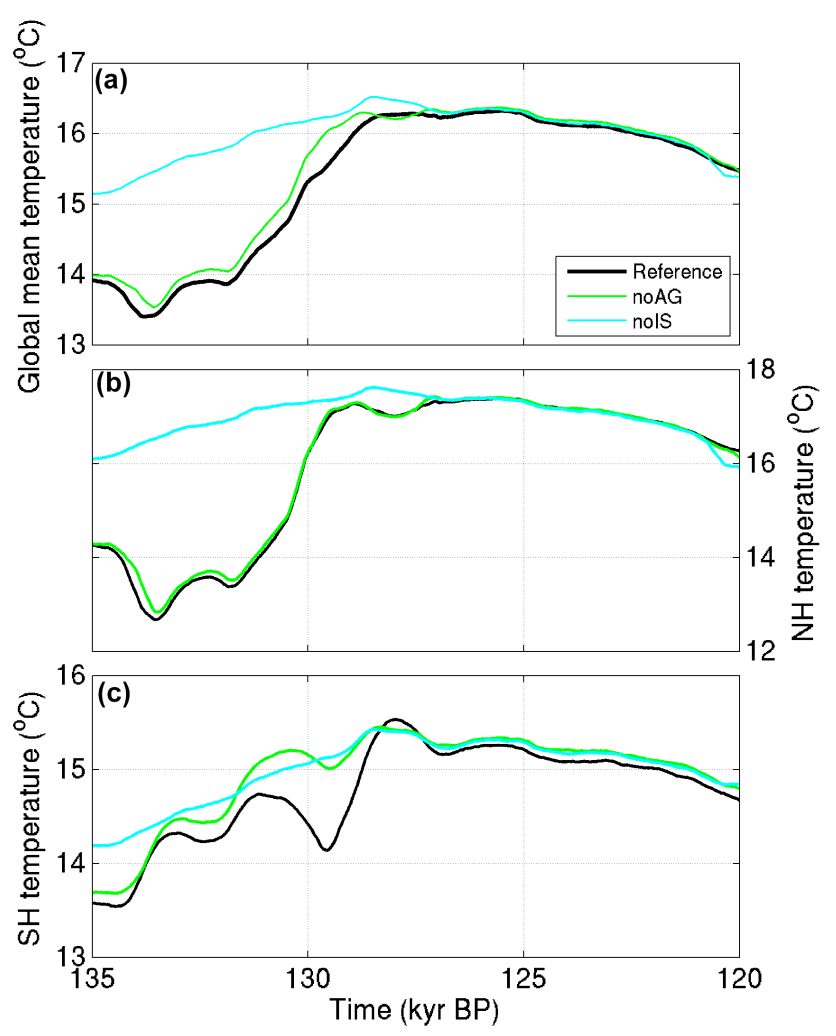

Figure 5. Evolution of global mean (a), northern hemispheric (b) and southern (c) hemispheric mean surface temperature for experiments with different ice sheet forcing included. Curves are smoothed with a running mean of 200 years for better comparison.

\section{Effect of GrIS and AIS on the temperature evolution at the onset of the LIG}

Including the forcing from the $\mathrm{NH}$ ice sheets in terms of configuration and FWFs has been shown by Loutre et al. (2014) to be crucial to simulate the onset of the LIG temperature increase and its amplitude variations more in line with proxy records. This helps to partially overcome problems of EMICs (and general circulation models) in simulating the strong temperature contrasts inferred from proxy reconstructions (Bakker et al., 2013; Lunt et al., 2013). The increased amplitude of temperature changes in our simulations is due to albedo and elevation changes in addition to the larger effect of the implied freshwater forcing from the $\mathrm{NH}$ ice sheets (Loutre et al., 2014). Here the Loutre et al. (2014) experiments are complemented with runs that additionally include changes in ice sheet configuration and FWFs from the GrIS and AIS. We first discuss the effect of including these additional ice sheet boundary conditions. A specific focus on the FWFs follows in Sect. 5.

The temperature evolution (Fig. 5) before $127 \mathrm{kyr}$ BP is in both hemispheres strongly influenced by the ice sheet boundary conditions and in particular by the freshwater forcing from the ice sheets. The experiments including FWFs from

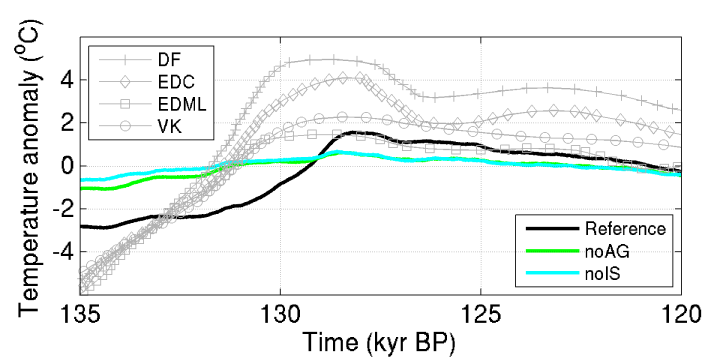

Figure 6. Comparison of modelled East Antarctic temperature evolution with reconstructed temperature changes at deep ice core sites. Modelled temperature anomalies are averaged over a region 72 $90^{\circ} \mathrm{S}$ and $0-150^{\circ} \mathrm{E}$. Ice core temperature reconstructions for the sites EPICA Dronning Maud Land (EDML; $75^{\circ} 00^{\prime} \mathrm{S}, 00^{\circ} 04^{\prime} \mathrm{E}$ ), Dome Fuji (DF; $77^{\circ} 19^{\prime} \mathrm{S}, 39^{\circ} 40^{\prime} \mathrm{E}$ ), Vostok (VK; $78^{\circ} 28^{\prime} \mathrm{S}$, $\left.106^{\circ} 48^{\prime} \mathrm{E}\right)$, and EPICA Dome C (EDC; $\left.75^{\circ} 06^{\prime} \mathrm{S}, 123^{\circ} 21^{\prime} \mathrm{E}\right)$ are from Masson-Delmotte et al. (2011).

the NH ice sheets (Reference and noAG) clearly show temperature variations on the multi-millennial timescale in both hemispheres following variations in ice sheet freshwater input (cf. Fig. 3). Differences in the temperature evolution between noAG and the reference experiment are small in the $\mathrm{NH}$, where the additional freshwater flux from Greenland is small compared to the other sources. In the $\mathrm{SH}$, by contrast, a large perturbation arises around $130 \mathrm{kyr} \mathrm{BP}$, when FWFs from the AIS peak. Global mean and hemispheric mean temperatures are similar in all runs after $\sim 127 \mathrm{kyr} \mathrm{BP}$, when the ice sheets have largely reached their interglacial configuration and FWFs are similar between the different experiments. An exception is the GrIS, which is retreating until $\sim 120 \mathrm{kyr}$ BP but accounts for only a small FWF contribution. The similarity of the results in the runs after $\sim 127 \mathrm{kyr}$ BP implies that the temporal memory of the response to ice sheet changes in the system is limited to the multi-centennial timescale, at least for the surface climate. The location of largest freshwater-induced temperature variations in the $\mathrm{NH}$ is the North Atlantic between 40 and $80^{\circ} \mathrm{N}$. Here changes in the AMOC cause a perturbation of the northward oceanic heat transport and temperature changes, which are further amplified by sea ice-albedo and insulation feedbacks. Greenland experiences maximum warming in the reference experiment around $125 \mathrm{kyr} \mathrm{BP}$ of up to $2.7^{\circ} \mathrm{C}$ in the annual mean compared to the pre-industrial era over remaining ice-covered central Greenland. Here the temperature evolution is largely similar to the experiment with GrIS changes not accounted for (noAG), which exhibits a maximum warming of $2.4^{\circ} \mathrm{C}$ (Loutre et al., 2014). However, the summer warming reaches up to $10^{\circ} \mathrm{C}$ at the northern margin and even up to $14^{\circ} \mathrm{C}$ over southern margins over a then ice-free tundra (not shown). The strong warming in the ice sheet periphery is due to a combination of elevation changes and local albedo changes, confined to the immediate region of ice sheet lowering and retreat. In the $\mathrm{SH}$, the largest temperature pertur- 

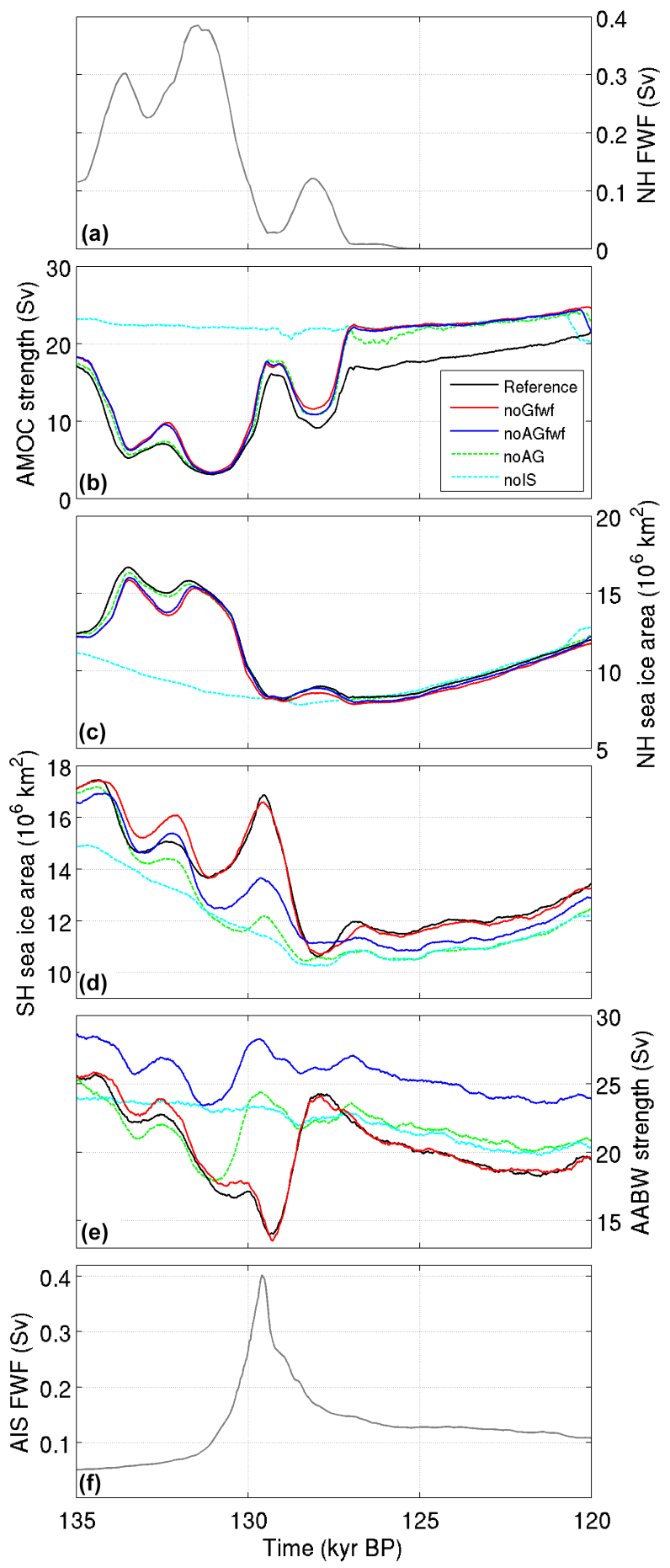

Figure 7. Freshwater forcing and oceanic response characteristics. NH (a) and Antarctic ice sheet freshwater fluxes (f), strength of the AMOC (b), NH sea ice area (c), SH sea ice area (d), and strength of $\mathrm{AABW}$ formation (e) for the different experiments with and without freshwater forcing from Greenland, Antarctic, and NH ice sheet melting. Curves are smoothed with a running mean of 200 years for better comparison. bations linked to both $\mathrm{NH}$ and $\mathrm{SH}$ freshwater fluxes occur in the SO. The largest warming over the ice sheet itself is simulated over the WAIS (not shown) and is mainly a consequence of the local elevation changes as the ice sheet retreats. However, mainly due to the marine-based character of the WAIS, albedo changes are much more limited compared to Greenland as the retreating ice sheet surface is mostly replaced by sea ice. Modelled temperature changes over the East Antarctic ice sheet (EAIS) have been compared to temperature reconstructions for four ice core locations (Fig. 6). The reference experiment shows a more pronounced warming between 135 and $129.5 \mathrm{kyr} \mathrm{BP}$ compared to the experiments excluding Antarctic ice sheet changes (noAG and noIS). While the modelled warming still appears to be underestimated and delayed compared to the reconstructions, the reference simulation clearly improves the representation of the EAIS temperature evolution compared to experiments with fixed Antarctic boundary conditions.

\section{Role of ice sheet meltwater fluxes}

To study the role of the different freshwater contributions from the ice sheets in more detail and evaluate their importance for the climate evolution, we compare additional simulations where FWFs from the GrIS and AIS are suppressed relative to the reference experiment (Fig. 7). The ice sheet configuration (topography and albedo) remains unchanged in these experiments. The effect of AIS FWFs can therefore be evaluated as the difference between noGfwf and noAGfwf, whereas the effect of GrIS FWFs becomes apparent from comparing the reference simulation with noGfwf. The AIS FWFs (Fig. 7f) lead to considerable changes in the SH but have very little impact on the NH temperature evolution (cf. Fig. 5b). Conversely, variations in the NH (Fig. 7a) and GrIS freshwater forcing on millennial timescales imply temperature changes in the $\mathrm{SH}$ on a background of general LIG warming.

Differences between the experiments in the AMOC evolution (Fig. 7b) are largely explained by whether FWFs from the NH ice sheets and the GrIS are included or not. Here AMOC strength is calculated as the maximum value of the meridional overturning stream function below the Ekman layer in the Atlantic Ocean between 45 and $65^{\circ} \mathrm{N}$. The effect of the FWFs from the GrIS (cf. Reference and noGfwf in Fig. 7b) is limited compared to the large impact of the general $\mathrm{NH}$ ice sheet forcing and consists of an additional weakening of the AMOC. It is most pronounced during periods of AMOC recovery and after $130 \mathrm{kyr} B P$, when melting of the GrIS beyond its present-day configuration sets in. Note that the simulated evolution of AMOC strength in the reference experiment is in good agreement with palaeo-evidence based on $\delta^{13} \mathrm{C}$ data (Bauch et al., 2012) and in particular with a recent reconstruction based on chemical water tracers (Böhm et al., 2015). The timing of Heinrich Stadial 11 ( 132 kyr BP) 
and the variations in AMOC strength after that are well captured by our reference simulation, which gives independent credibility to our $\mathrm{NH}$ ice sheet reconstructions.

The evolution of $\mathrm{NH}$ sea ice area (Fig. 7c) generally shows maxima at times of AMOC minima and vice versa and is closely linked to $\mathrm{NH}$ surface temperature variations (cf. Fig. 5b) by modifying the heat exchange between ocean and atmosphere. The largest sea ice area between 135 and $130 \mathrm{kyr} \mathrm{BP}$ is simulated in the reference experiment, which also exhibits the lowest AMOC strength of all experiments.

The situation in the SH is more complex as surface temperature and sea ice evolution are influenced by freshwater forcing from the AIS and also by the FWFs in the NH. The AMOC variability gives rise to changes in the SH through the so-called interhemispheric see-saw effect (Stocker, 1998). The SH begins to warm as the NH cools due to modified oceanic heat transport across the equator. Minima in SH temperature (cf. Fig. 5c) and maxima in SH sea ice area (Fig. 7d) are therefore associated with maxima in AMOC strength. The additional effect of including GrIS freshwater forcing is consequently also felt in a warmer $\mathrm{SH}$ with less sea ice formation. However, the influence of GrIS freshwater fluxes and consequential AMOC variations on the SH temperature appears to be mostly limited to the beginning of the experiment between $\sim 135$ and $131 \mathrm{kyr}$ BP. It could be speculated that this is related to the larger extent of the SH sea ice in a colder climate, making the system more sensitive due to an increased potential for sea ice-albedo and insulation feedbacks. We also note that modelled periods of increased $\mathrm{NH}$ freshwater fluxes, reduced AMOC strength, and higher $\mathrm{SH}$ temperatures are roughly in phase with periods of steeper increase in GHG concentrations (cf. Fig. 4b), in line with evidence from marine sediment proxies that indicate that $\mathrm{CO}_{2}$ concentration rose most rapidly when North Atlantic Deep Water shoaled (Ahn and Brook, 2008). Since GHGs and NH freshwater fluxes are (independently) prescribed in our experiments, the described in-phase relationship lends further credibility to our NH ice sheet reconstruction.

The FWF from AIS melting (Fig. 7f) increases the SO sea ice area (Fig. 7d) by freshening and stratifying the upper ocean waters, which in turn leads to lower surface temperatures. In our experiments, the increased freshwater flux from the retreating AIS (cf. noGfwf versus noAGfwf) between 131 and $129 \mathrm{kyr}$ BP is in phase with a period of transient AMOC strengthening (Fig. 7b), which leads to a combined effect of surface cooling and sea ice expansion in the SO.

The formation of AABW is strongly controlled by salinity and sea ice area (and therefore temperature) of the polar surface waters and hence directly by Antarctic freshwater fluxes and indirectly by $\mathrm{NH}$ freshwater fluxes. Here the strength of $\mathrm{AABW}$ formation is calculated as the minimum value of the global meridional overturning stream function below the Ekman layer south of $60^{\circ} \mathrm{S}$. The AABW formation (Fig. 7e) is stronger for saltier and colder surface conditions and therefore strongest in the case of noAGfwf, where FWFs are sup- pressed from the AIS (saltier) and the GrIS (colder). For a similar Antarctic freshwater forcing, the AABW formation is stronger for a larger SH sea ice area. Including Antarctic FWFs leads to a generally weaker AABW formation as surface waters become fresher (cf. noGfwf versus noAGfwf). These relationships also imply that a stronger decrease in AABW formation, associated with decreased $\mathrm{CO}_{2}$ uptake by the ocean can be found for periods of steeper increase in prescribed radiative forcing. Again, this appears to support consistency in timing between prescribed radiative and $\mathrm{NH}$ ice sheet forcing in our modelling.

\section{Temperature evolution in the Southern Hemisphere}

Millennial-scale sea-surface temperature variations in the $\mathrm{SH}$ induced by $\mathrm{NH}$ freshwater fluxes are the strongest in the $\mathrm{SO}$, where anomalies can be amplified by sea ice-albedo and insulation feedbacks. This is also the region that experiences the largest temperature change due to FWFs from the AIS itself (not shown).

In order to study the effect of Antarctic FWFs in more detail, we also analysed the oceanic temperature evolution south of $63^{\circ} \mathrm{S}$ (Fig. 8). The effect of the AIS freshwater flux in the reference experiment (compare noAGfwf with reference) becomes visible in the sea surface temperature after $132 \mathrm{kyr} \mathrm{BP}$ (Fig. 8a) as a cooling due to stratification and sea ice expansion (Fig. 8c). At the same time, the subsurface ocean warms (Fig. 8b) as heat is trapped under the stratified surface waters and expanding sea ice area. When the FWFs decline towards the end of the AIS retreat around $128 \mathrm{kyr} \mathrm{BP}$, sea ice retreats again and the heat is released to the atmosphere, where it generates an overshoot in sea surface temperature compared to the experiment with constant Antarctic freshwater fluxes (noAGfwf). The largest effect of this heat buffering is found in winter in regions of strongest warming in the Bellingshausen Sea and off the Gunnerus Ridge adjacent to Dronning Maud Land. The maximum sea ice extent in the SH (Fig. 8c) occurs at the time of largest surface cooling at $129.5 \mathrm{kyr}$ BP. This freshwater-induced surface cooling at the onset of the LIG appears to be superficial and relatively short-lived and of clearly different signature compared to, for example, the Antarctic cold reversal during the last deglaciation. The cooling event is indeed not recorded in our modelled temperature evolution over central East Antarctica, in line with a lack of its signature in Antarctic ice core records for that time period (Petit et al., 1999; EPICA community members, 2004). A sea ice expansion during Termination II together with an oceanic cold reversal around $129.5 \mathrm{kyr}$ BP (Fig. 8c) is, however, recorded in some deep-sea sediment cores, where the composition of planktonic diatoms suggests meltwater as the primary cause (Bianchi and Gersonde, 2002; Cortese and Abelmann, 2002). 

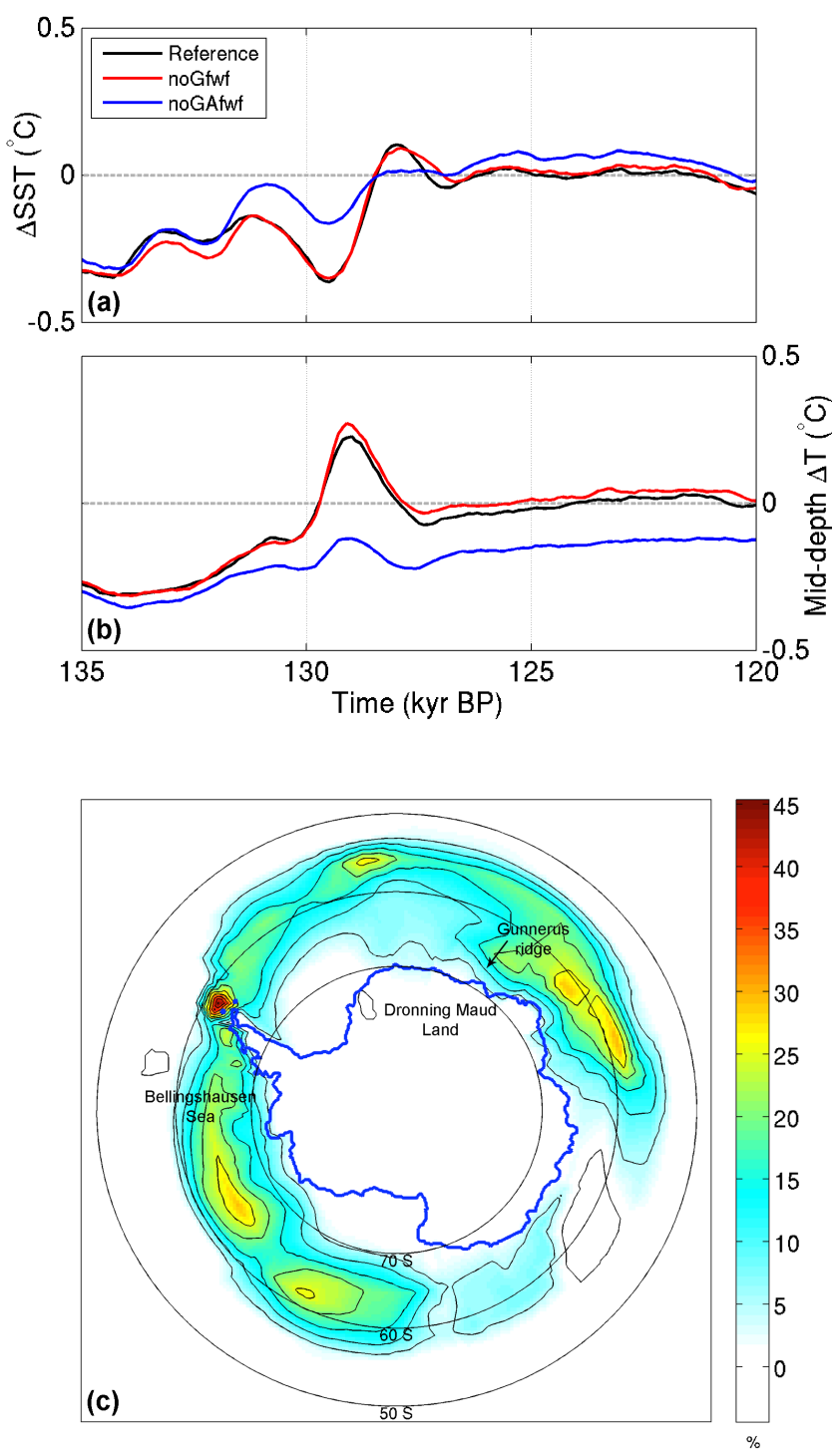

Figure 8. Evolution of annual mean sea surface temperature (a) and mid-depth $(485-700 \mathrm{~m})$ ocean temperature (b) anomalies relative to the pre-industrial era in close proximity to the AIS (south of $63^{\circ} \mathrm{S}$ ). (c) Meltwater-related changes in annual mean sea ice area at 129.5 kyr BP from differences between experiments Reference and noAGfwf in per cent. The blue contour outlines the observed iceshelf edge and grounded ice margin of the present-day AIS for illustration. All curves $(\mathbf{a}, \mathbf{b})$ are smoothed with a running mean of 200 years for better comparison.

As a further consequence, the timing of maximum annual mean surface air temperature (defined as MWT for maximum warmth timing; Bakker et al., 2013) in the SO differs by several thousand years between experiments (Fig. 9). Including Antarctic FWFs leads to an earlier MWT (by up to $2 \mathrm{kyr}$ ) in large parts of the SO south of $60^{\circ} \mathrm{S}$ and in the central and eastern parts of the Atlantic sector of the SO up to $40^{\circ} \mathrm{S}$ (Fig. 9d). Conversely, a later MWT (by up to $3 \mathrm{kyr}$ ) is found in the Indian and Pacific sectors of the SO north

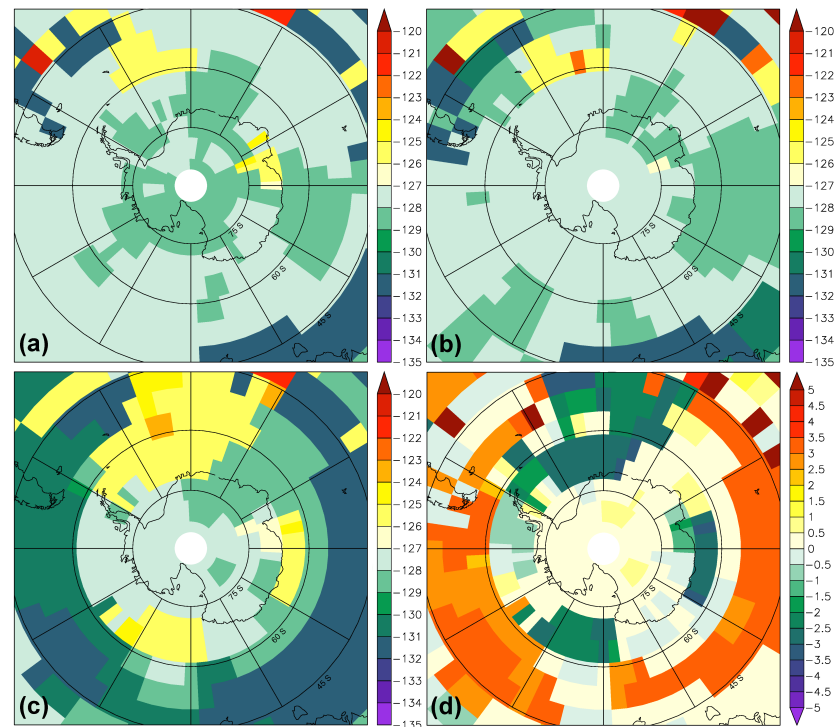

Figure 9. Time of maximum surface air temperature (MWT) in kyrBP for experiments Reference (a), noGfwf (b), and noAGfwf (c) and difference in MWT between experiments noGfwf and noAGfwf (d) in kyr, showing the shift of the MWT when Antarctic freshwater fluxes are included.

of $60^{\circ} \mathrm{S}$ when Antarctic FWFs are accounted for (Fig. 9d). In the reference experiment (Fig. 9a) and noGfwf (Fig. 9b), the MWT lies relatively homogeneously between -129 and $-128 \mathrm{kyr}$ for the entire SO south of $45^{\circ} \mathrm{S}$ and coincides with the overshoot in sea surface temperature after the peak input of Antarctic FWFs. The observed changes in the MWT in the SO due to the additional Antarctic freshwater input can therefore in either way be understood as a shift towards the time when heat from the mid-depth ocean buffer is released to the surface.

\section{Discussion}

Despite remaining uncertainties in the timing of ice sheet retreat during Termination II, we find several lines of evidence in support of our ice sheet reconstructions and the associated climatic signatures. The NH ice sheet reconstruction shows some similarity with the IRD signal recorded in North Atlantic sediment cores (Kandiano et al., 2004; Oppo et al., 2006), while the simulated evolution of the AMOC strength (Fig. 7a) is in good agreement with a recent reconstruction based on chemical water tracers (Böhm et al., 2015). The combination of $\mathrm{NH}$ - and $\mathrm{SH}$-sourced freshwater forcing variations produces a stronger decrease in AABW formation, associated with decreased $\mathrm{CO}_{2}$ uptake by the ocean for periods of steeper increase in prescribed radiative forcing, in line with evidence from marine sediment proxies that indicate that $\mathrm{CO}_{2}$ concentration rose most rapidly when North Atlantic Deep Water shoaled (Ahn and Brook, 2008). Re- 
constructing the $\mathrm{NH}$ ice sheet evolution during Termination II with the same method but using the Grant et al. (2012) sea-level record for comparison with Termination I has been shown to worsen agreement of the modelled climate with proxy reconstructions (Loutre et al., 2014).

Our modelling results furthermore suggest that the major AIS retreat from its glacial configuration could be constrained by an oceanic cold event recorded in several SO sediment cores around Antarctica (Bianchi and Gersonde, 2002; Cortese and Abelmann, 2002). As a schematic sensitivity test to uncertainties in the overall glacial AIS volume and retreat rate, we have performed one more experiment identical to the reference experiment except for Antarctic FWFs scaled to $50 \%$ of their reference value. The resulting magnitude of the SO cold event and overshoot is lower but exhibits the same timing and spatial expression as in the reference case. The described mechanisms and effects can therefore be considered robust to differences in the magnitude of the freshwater flux, resulting from uncertainties in glacial ice volume or AIS retreat rate. Notably, the improved representation of the central East Antarctic temperature evolution in the model when including Antarctic ice sheet changes (Fig. 6) is largely independent of the chosen freshwater forcing. This implies that changes in the geometry of the ice sheet and modified atmospheric circulation patterns are the cause of the stronger simulated temperature contrast.

The GrIS is generally assumed to have remained largely intact during the LIG (e.g. Robinson et al., 2011; Colville et al., 2011; Stone et al., 2013; NEEM community members, 2013) and indirect evidence of its freshwater contribution may be difficult to find due to the low amplitude compared to the other NH ice sheets. However, recent ice core reconstructions of the temperature evolution at the NEEM ice core site (NEEM community members, 2013) point to a late retreat with a peak sea-level contribution close to $120 \mathrm{kyr}$ BP. The GrIS can be assumed to lose mass approximately as long as the temperature anomaly above the ice sheet remains above zero. Based on the NEEM record, which has been used as forcing time series in our stand-alone GrIS experiment, FWF from the GrIS peaks at $\sim 125 \mathrm{kyr}$ BP but remains elevated until around $120 \mathrm{kyr} B \mathrm{P}$ above the steady-state background flux of an ice sheet in equilibrium with the climate. The additional FWF from melting of the GrIS results in relatively low temperatures over southeastern Greenland in response to a weakening of the AMOC (not shown). The interaction between GrIS meltwater fluxes and oceanic circulation hence gives rise to a negative feedback on ice sheet retreat. This aspect could play an important role for the stability of the southern dome of the ice sheet and should be examined further with fully coupled climate-ice sheet simulations.

In general, the $\mathrm{NH}$ freshwater forcing leads to variations in the strength of the AMOC and North Atlantic cooling and additionally, through the bipolar see-saw effect, to temperature changes in the SH. The only moment mid-depth ocean temperatures close to AIS grounding lines are above pre- industrial values in our experiments is during the oceanic cold reversal around $129.5 \mathrm{kyr} \mathrm{BP}$, induced by anomalous FWFs from the retreating AIS. During this period, SO middepth temperature anomalies relative to the pre-industrial era reach up to $0.3 \mathrm{~K}$, which could provide a positive but rather limited feedback on ice sheet retreat, similar to what has been suggested by Golledge et al. (2014) for meltwater pulse 1A during Termination I. However, the oceanic warming recorded in our model is not strong and the duration of the perturbation does not appear to be long enough for a sustained impact on the retreat of the ice sheet. Furthermore, the peak in freshwater flux appears when the ice sheet has already retreated considerably and WAIS grounding lines are located mostly on the continental shelves, more protected from the warm water build-up in the mid-depth ocean. A large-scale marine ice sheet retreat of the likely less vulnerable EAIS sectors (Mengel and Levermann, 2014) appears particularly unlikely, given the atmospheric and oceanic forcing at the time apparent in our modelling results. However, in-depth studies of these interactions require detailed coupled simulations of the entire ocean-ice sheet system.

Despite aforementioned lines of evidence in support of the reconstructed $\mathrm{NH}$ ice sheet evolution, a limitation to our modelling approach is the rescaling of ice sheet retreat during Termination I, an attempt to address the sparseness of geomorphological field evidence for Termination II. An alternative approach would be to physically model all ice sheets together in one framework (e.g. de Boer et al., 2013), although spatial and temporal resolution of the models is a limiting factor in that specific case. A rigorous modelling approach like the latter could also help to prevent possible inconsistencies when combining ice sheet reconstructions from different approaches. Nevertheless, any modelling approach will ultimately be confronted with the same problem of scarce data for model validation during that period. The exclusion of climate feedbacks on ice sheet evolution of our present one-way coupled modelling approach is a general limitation, which we have addressed in a separate study with a fully coupled model setup (Goelzer et al., 2016).

\section{Conclusions}

We have presented a transient simulation of Termination II and the Last Interglacial period with realistic ice sheet boundary conditions from reconstructed $\mathrm{NH}$ ice sheets and detailed stand-alone simulations of the Greenland and Antarctic ice sheets. Our results show that the temperature evolution at the onset of the Last Interglacial was in both hemispheres considerably influenced by meltwater fluxes from the retreating ice sheets. While Antarctic freshwater fluxes lead to strong perturbations of the Southern Ocean, $\mathrm{NH}$ freshwater fluxes have an influence on both $\mathrm{NH}$ and $\mathrm{SH}$ temperature evolution through the oceanic see-saw effect. The importance of additional freshwater input from the 
GrIS during Termination II is small compared to the much larger fluxes from the other $\mathrm{NH}$ ice sheets and becomes more important only later during the Last Interglacial, when it is the only remaining ice sheet contributing freshwater fluxes to the North Atlantic. In the SH, anomalous freshwater input from the AIS leads to an episode of surface freshening, increased stratification, and sea ice cover and consequently reduced ocean heat loss to the atmosphere, with temporary heat build-up in the mid-depth ocean. We argue that the surface ocean cooling associated with this event may be used to constrain an early Antarctic retreat when matched with similar signatures evident in some deep-sea sediment cores from the Southern Ocean.

Our transient simulations confirm results from earlier studies that stress the importance of ice sheet boundary conditions for the climate evolution at the onset of the LIG. However, most of the freshwater-induced changes remain visible for at most 1-2 kyr after cessation of the perturbations, indicative of a relative short memory of the (surface) climate system. Additional effects may arise from climate-ice sheet feedbacks not considered in the present model configuration, which should be investigated in fully coupled experiments.

\section{Data availability}

The LOVECLIM version 1.3 model code can be downloaded from http://www.elic.ucl.ac.be/modx/elic/index.php?id=289. 


\section{Appendix A: Reconstruction of $\mathrm{NH}$ ice sheet forcing}

A direct reconstruction of $\mathrm{NH}$ ice sheet evolution during Termination II based on geomorphological data is not possible, due to the scarcity of field evidence that was mostly destroyed by the re-advancing ice sheets during the last glacial period. Therefore, a reconstruction of Termination II is made by remapping the much better constrained ice sheet retreat of Termination I.

\section{A1 Ice extent during Termination I}

The evolution of the NH ice extent since the LGM was estimated based on published sources (Table A1) dating back to the time of the NH ice sheet studies of Zweck and Huybrechts $(2003,2005)$. For the large Laurentide and Eurasian ice sheets, inferred ice extents are relatively well determined from geomorphological data and the reconstruction remains in good agreement with most recent sources (e.g. Hughes et al., 2016). For smaller ice sheets such as the European Alps, previous modelled ice extent was used (Zweck and Huybrechts, 2005).

For ice sheets with multiple sources of data the isochrones were merged using the most recent source when conflicts occurred (e.g. Dyke et al., 2002, instead of Dyke and Prest, 1987, for the Innuitian ice sheet, Svendsen et al., 1999, instead of Andersen, 1981, for the LGM maximum of the Eurasian ice sheet). The most recent source was then used as a mask of maximum ice extent for most recent isochrones of all sources. The only region which experienced an advance in ice extent using this technique was the southern Cordilleran ice sheet according to the reconstruction of Clague and James (2002).

The INTCAL98 timescale of Stuiver et al. (1998) was used to convert radiocarbon dates to calendar years for the sources in Table A1. The retreat of the ice sheets between the LGM and present day was prescribed at 200-year resolution. Even for well-determined geomorphological observations, uncertainties in dating and from the conversion of radiocarbon to calendar years well exceed the 200-year temporal resolution used here. Fig. A1 in Appendix A1 shows the deglaciation chronology reconstructed in this manner.

\section{A2 Ice sheet elevations during Termination I}

The NH ice sheets introduced significant changes to the surface topography of the region. As LOVECLIM1.3 has only three atmospheric height levels, details regarding topography are not strongly sensed. To include changes in surface topography in the model, parabolic profile ice sheets are constructed using the extents shown in Fig. A1, neglecting isostatic adjustment (i.e. present-day surface elevation of the Earth's surface). The basal shear stress for the parabolic profile reconstruction is chosen so that the difference in ice volume between LGM and present day corresponds to $86 \mathrm{~m}$ of
Table A1. Sources of geomorphological data or modelling results used to prescribe changes in Northern Hemisphere ice sheet extent for the retreat during Termination I.

\begin{tabular}{|c|c|c|}
\hline Ice sheet & Source & $\begin{array}{l}\text { Isochrone time period } \\
\text { (kyr BP) }\end{array}$ \\
\hline Laurentide & Dyke and Prest (1987) & 18-present day \\
\hline Innuitian & Dyke et al. (2002) & 18 \\
\hline \multirow[t]{4}{*}{ Cordilleran } & Clague and James (2002) & 20-present day (south) \\
\hline & Dyke et al. (2002) & \\
\hline & Mayewski et al. (1981) & 18 (north) \\
\hline & & 21-7 (interior) \\
\hline Iceland & Andersen (1981) & 20 -present day \\
\hline \multirow[t]{4}{*}{ Eurasian } & Andersen (1981) & 20 -present day \\
\hline & Landvik et al. (1998) & 15-12 (Barents Sea) \\
\hline & Mangerud et al. (2002) & $\begin{array}{l}18 \text { (southern Barents } \\
\text { and Kara seas) }\end{array}$ \\
\hline & Svendsen et al. (1999) & 18 \\
\hline European Alps & Zweck and Huybrechts (2003) & $\begin{array}{l}\text { 21-present day } \\
\text { (modelled ice extent) }\end{array}$ \\
\hline
\end{tabular}

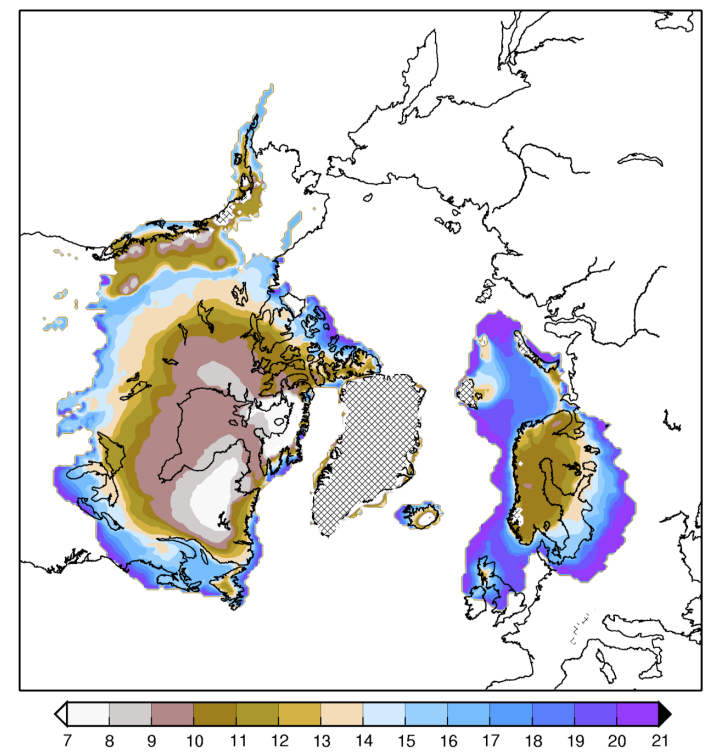

Figure A1. Interpolated ice sheet extent during the last deglaciation for the Northern Hemisphere ice sheets as a function of time $(\mathrm{kyr} B P)$. Hatched regions indicate present-day ice.

eustatic sea-level change. With isostasy accounted for, a similar elevation would result in an additional contribution of $24 \mathrm{~m}$ to a total equivalent eustatic sea-level change of $110 \mathrm{~m}$ (cf. Zweck and Huybrechts, 2005). Using this procedure the maximum elevation of the Laurentide ice sheet is $3000 \mathrm{~m}$ near present-day Churchill in Hudson Bay, and the maximum elevation of the Eurasian ice sheet is $2600 \mathrm{~m} 100 \mathrm{~km}$ west of present-day Helsinki.

\section{A3 Remapping Termination I to Termination II}

Remapping of the retreat during Termination I to Termination II is done using a benthic $\delta^{18} \mathrm{O}$ record (Lisiecki and 
Raymo, 2005), assumed as an indicator of the global ice volume. In practice, the $\mathrm{NH}$ ice sheet configuration for a given time (and $\delta^{18} \mathrm{O}$ value) during Termination II is taken from a time during Termination I when the $\delta^{18} \mathrm{O}$ value had the same value. The LGM sea-level contribution of the NH ice sheets relative to the present day of $-110 \mathrm{~m}$ translates into a similar magnitude for the penultimate glacial maximum (Lisiecki and Raymo, 2005). The resulting NH ice volume evolution for Termination II is shown in Fig. 3a. However, the method does not guarantee that the sea-level contribution of the reconstructed NH ice sheets closely follows the global ice volume curve. This is generally due to the mismatch between global ice volume and $\mathrm{NH}$ ice sheet reconstruction during Termination I, and in part related to the unconstrained contribution of other components (AIS, thermal expansion). Due to the assumed analogy, different configurations of the $\mathrm{NH}$ ice sheets (e.g. Obrochta et al., 2014) and different relative timing of $\mathrm{NH}$ and $\mathrm{SH}$ deglaciation between last and penultimate glaciation are not represented in these reconstructions. $\mathrm{NH}$ freshwater fluxes were estimated from the same method by using derived volume changes as input to a continental runoff-routing model (Goelzer et al., 2012b) to identify the magnitude and location of meltwater fluxes to the ocean. 
Acknowledgements. We acknowledge support through the Belgian Federal Science Policy Office within its Research Programme on Science for a Sustainable Development under contract SD/CS/06A (iCLIPS). Computational resources were provided by the supercomputing facilities of the Universite catholique de Louvain (CISM/UCL) and the Consortium des Equipements de Calcul Intensif en Fédération Wallonie Bruxelles (CECI), funded by the Fond de la Recherche Scientifique de Belgique (FRS-FNRS). We thank the two anonymous reviewers and the editor for constructive comments and their follow-up of the manuscript.

Edited by: G. Lohmann

Reviewed by: two anonymous referees

\section{References}

Ahn, J. and Brook, E.: Atmospheric $\mathrm{CO}_{2}$ and climate on millennial time scales during the last glacial period, Science, 322, 83-85, doi:10.1126/science.1160832, 2008.

Andersen, B. G.: Late Weichselian ice sheets in Eurasia and Greenland, in: The Last Great Ice Sheets, edited by: Denton, G. H. and Hughes, T. J., Wiley Interscience, New York, 1-65, 1981.

Bakker, P., Stone, E. J., Charbit, S., Gröger, M., Krebs-Kanzow, U., Ritz, S. P., Varma, V., Khon, V., Lunt, D. J., Mikolajewicz, U., Prange, M., Renssen, H., Schneider, B., and Schulz, M.: Last interglacial temperature evolution - a model inter-comparison, Clim. Past, 9, 605-619, doi:10.5194/cp-9-605-2013, 2013.

Barker, S., Knorr, G., Edwards, R. L., Parrenin, F., Putnam, A. E., Skinner, L. C., Wolff, E., and Ziegler, M.: 800000 Years of Abrupt Climate Variability, Science, 334, 347-351, doi:10.1126/science.1203580, 2011.

Bauch, H. A., Kandiano, E. S., and Helmke, J. P.: Contrasting ocean changes between the subpolar and polar North Atlantic during the past $135 \mathrm{ka}$, Geophys. Res. Lett., 39, L11604, doi:10.1029/2012GL051800, 2012.

Berger, A.: Long-term variations of daily insolation and Quaternary climatic changes, J. Atmos. Sci., 35, 2362-2367, 1978.

Bianchi, C. and Gersonde, R.: The Southern Ocean surface between Marine Isotope Stages 6 and 5d: Shape and timing of climate changes, Palaeogeogr. Palaeocl., 187, 151-177, doi:10.1016/S0031-0182(02)00516-3, 2002.

Bintanja, R., Van Oldenborgh, G. J., Drijfhout, S. S., Wouters, B., and Katsman, C. A.: Important role for ocean warming and increased ice-shelf melt in Antarctic sea-ice expansion, Nat. Geosci., 6, 376-379, doi:10.1038/ngeo1767, 2013.

Böhm, E., Lippold, J., Gutjahr, M., Frank, M., Blaser, P., Antz, B., Fohlmeister, J., Frank, N., Andersen, M. B., and Deininger, M.: Strong and deep Atlantic meridional overturning circulation during the last glacial cycle, Nature, 517, 73-76 doi:10.1038/nature14059, 2015.

Born, A. and Nisancioglu, K. H.: Melting of Northern Greenland during the last interglaciation, Cryosphere, 6, 1239-1250, doi:10.5194/tc-6-1239-2012, 2012.

Brovkin, V., Ganopolski, A., and Svirezhev, Y.: A continuous climate-vegetation classification for use in climate-biosphere studies, Ecol. Model., 101, 251-261, doi:10.1016/S03043800(97)00049-5, 1997.

Capron, E., Govin, A., Stone, E. J., Masson-Delmotte, V., Mulitza, S., Otto-Bliesner, B., Rasmussen, T. L., Sime, L. C., Wael- broeck, C., and Wolff, E. W.: Temporal and spatial structure of multi-millennial temperature changes at high latitudes during the Last Interglacial, Quaternary Sci. Rev., 103, 116-133, doi:10.1016/j.quascirev.2014.08.018, 2014.

Clague, J. J. and James, T. S.: History and isostatic effects of the last ice sheet in southern British Columbia, Quaternary Sci. Rev., 21, 71-87, doi:10.1016/s0277-3791(01)00070-1, 2002.

Colville, E. J., Carlson, A. E., Beard, B. L., Hatfield, R. G., Stoner, J. S., Reyes, A. V., and Ullman, D. J.: Sr-Nd-Pb Isotope Evidence for Ice-Sheet Presence on Southern Greenland During the Last Interglacial, Science, 333, 620-623, doi:10.1126/science.1204673, 2011.

Cortese, G. and Abelmann, A.: Radiolarian-based paleotemperatures during the last $160 \mathrm{kyr}$ at ODP Site 1089 (Southern Ocean, Atlantic Sector), Palaeogeogr. Palaeocl., 182, 259-286, doi:10.1016/S0031-0182(01)00499-0, 2002.

de Boer, B., van de Wal, R. S. W., Lourens, L. J., Bintanja, R., and Reerink, T. J.: A continuous simulation of global ice volume over the past 1 million years with 3-D ice-sheet models, Clim. Dynam., 41, 1365-1384, doi:10.1007/s00382-012-1562-2, 2013.

Driesschaert, E., Fichefet, T., Goosse, H., Huybrechts, P., Janssens, I., Mouchet, A., Munhoven, G., Brovkin, V., and Weber, S.: Modeling the influence of Greenland ice sheet melting on the Atlantic meridional overturning circulation during the next millennia, Geophys. Res. Lett., 34, L10707, doi:10.1029/2007GL029516, 2007.

Duplessy, J. C., Roche, D. M., and Kageyama, M.: The deep ocean during the last interglacial period, Science, 316, 89-91, doi:10.1126/science.1138582, 2007.

Dutton, A. and Lambeck, K.: Ice Volume and Sea Level During the Last Interglacial, Science, 337, 216-219, doi:10.1126/science.1205749, 2012.

Dyke, A. S. and Prest, V. K.: Late Wisconsinan and Holocene history of the Laurentide Ice Sheet, Géog. Phys. Quat., 41, 237-263, doi:10.7202/032681ar, 1987.

Dyke, A. S., Andrews, J. T., Clark, P. U., England, J., Miller, G. H., Shaw, J., and Veillette, J. J.: The Laurentide and Innuitian ice sheets during the Last Glacial Maximum, Quaternary Sci. Rev., 21, 9-31, doi:10.1016/S0277-3791(01)00095-6, 2002.

EPICA community members: Eight glacial cycles from an Antarctic ice core, Nature, 429, 623-628, doi:10.1038/Nature02599, 2004.

Fürst, J. J., Goelzer, H., and Huybrechts, P.: Ice-dynamic projections of the Greenland ice sheet in response to atmospheric and oceanic warming, The Cryosphere, 9, 1039-1062, doi:10.5194/tc-9-1039-2015, 2015.

Goelzer, H., Huybrechts, P., Loutre, M. F., Goosse, H., Fichefet, T., and Mouchet, A.: Impact of Greenland and Antarctic ice sheet interactions on climate sensitivity, Clim. Dynam., 37, 1005-1018, doi:10.1007/s00382-010-0885-0, 2011.

Goelzer, H., Huybrechts, P., Raper, S. C. B., Loutre, M. F., Goosse, H., and Fichefet, T.: Millennial total sea level commitments projected with the Earth system model of intermediate complexity LOVECLIM, Environ. Res. Lett., 7, 045401, doi:10.1088/17489326/7/4/045401, 2012a.

Goelzer, H., Janssens, I., Nemec, J., and Huybrechts, P.: A dynamic continental runoff routing model applied to the last Northern Hemisphere deglaciation, Geosci. Model Dev., 5, 599-609, doi:10.5194/gmd-5-599-2012, 2012b. 
Goelzer, H., Huybrechts, P., Loutre, M.-F., and Fichefet, T.: Last Interglacial climate and sea-level evolution from a coupled ice sheet-climate model, Clim. Past Discuss., doi:10.5194/cp-2015175, in review, 2016.

Golledge, N. R., Menviel, L., Carter, L., Fogwill, C. J., England, M. H., Cortese, G., and Levy, R. H.: Antarctic contribution to meltwater pulse 1A from reduced Southern Ocean overturning, Nat. Commun., 5, 5107, doi:10.1038/ncomms6107, 2014.

Goosse, H. and Fichefet, T.: Importance of ice-ocean interactions for the global ocean circulation: A model study, J. Geophys. Res., 104, 23337-23355, doi:10.1029/1999JC900215, 1999.

Goosse, H., Brovkin, V., Fichefet, T., Haarsma, R., Huybrechts, P., Jongma, J., Mouchet, A., Selten, F., Barriat, P.-Y., Campin, J.M., Deleersnijder, E., Driesschaert, E., Goelzer, H., Janssens, I., Loutre, M.-F., Morales Maqueda, M. A., Opsteegh, T., Mathieu, P.-P., Munhoven, G., Pettersson, E. J., Renssen, H., Roche, D. M., Schaeffer, M., Tartinville, B., Timmermann, A., and Weber, S. L.: Description of the Earth system model of intermediate complexity LOVECLIM version 1.2, Geosci. Model Dev., 3, 603-633, doi:10.5194/gmd-3-603-2010, 2010.

Govin, A., Braconnot, P., Capron, E., Cortijo, E., Duplessy, J.-C., Jansen, E., Labeyrie, L., Landais, A., Marti, O., Michel, E., Mosquet, E., Risebrobakken, B., Swingedouw, D., and Waelbroeck, C.: Persistent influence of ice sheet melting on high northern latitude climate during the early Last Interglacial, Clim. Past, 8, 483-507, doi:10.5194/cp-8-483-2012, 2012.

Grant, K. M., Rohling, E. J., Bar-Matthews, M., Ayalon, A., Medina-Elizalde, M., Ramsey, C. B., Satow, C., and Roberts, A. P.: Rapid coupling between ice volume and polar temperature over the past 150000 years, Nature, 1-4, doi:10.1038/nature11593, 2012.

Greve, R., Saito, F., and Abe-Ouchi, A.: Initial results of the SeaRISE numerical experiments with the models SICOPOLIS and IcIES for the Greenland ice sheet, Ann. Glaciol., 52, 23-30, doi:10.3189/172756411797252068, 2011.

Holden, P. B., Edwards, N. R., Wolff, E. W., Lang, N. J., Singarayer, J. S., Valdes, P. J., and Stocker, T. F.: Interhemispheric coupling, the West Antarctic Ice Sheet and warm Antarctic interglacials, Clim. Past, 6, 431-443, doi:10.5194/cp-6-431-2010, 2010.

Hughes, A. L. C., Gyllencreutz, R., Lohne, Ø. S., Mangerud, J., and Svendsen, J. I.: The last Eurasian ice sheets - a chronological database and time-slice reconstruction, DATED-1, Boreas, 45, 1-45, doi:10.1111/bor.12142, 2016.

Huybrechts, P.: A 3-D model for the Antarctic Ice Sheet: a sensitivity study on the glacial-interglacial contrast, Clim. Dynam., 5, 79-92, doi:10.1007/BF00207423, 1990.

Huybrechts, P.: Sea-level changes at the LGM from ice-dynamic reconstructions of the Greenland and Antarctic ice sheets during the glacial cycles, Quaternary Sci. Rev., 21, 203-231, doi:10.1016/S0277-3791(01)00082-8, 2002.

Kandiano, E. S., Bauch, H. A., and Müller, A.: Sea surface temperature variability in the North Atlantic during the last two glacialinterglacial cycles: comparison of faunal, oxygen isotopic, and $\mathrm{Mg} / \mathrm{Ca}$-derived records, Palaeogeogr. Palaeocl., 204, 145-164, doi:10.1016/S0031-0182(03)00728-4, 2004.

Kopp, R. E., Simons, F. J., Mitrovica, J. X., Maloof, A. C., and Oppenheimer, M.: Probabilistic assessment of sea level during the last interglacial stage, Nature, 462, 863-867, doi:10.1038/nature08686, 2009.
Kopp, R. E., Simons, F. J., Mitrovica, J. X., Maloof, A. C., and Oppenheimer, M.: A probabilistic assessment of sea level variations within the last interglacial stage, Geophys. J. Int., 193, 711-716, doi:10.1093/gji/ggt029, 2013.

Landvik, J. Y., Bondevik, S., Elverhøi, A., Fjeldskaar, W., Mangerud, J., Salvigsen, O., Siegert, M. J., Svendsen, J. I., and Vorren, T. O.: The Last Glacial Maximum of Svalbard and the Barents Sea area: ice sheet extent and configuration, Quaternary Sci. Rev., 17, 43-75, doi:10.1016/S0277-3791(97)00066-8, 1998.

Langebroek, P. M. and Nisancioglu, K. H.: Simulating last interglacial climate with NorESM: role of insolation and greenhouse gases in the timing of peak warmth, Clim. Past, 10, 1305-1318, doi:10.5194/cp-10-1305-2014, 2014.

Letréguilly, A., Huybrechts, P., and Reeh, N.: Steady-state characteristics of the Greenland ice sheet under different climates, J. Glaciol., 37, 149-157, 1991.

Lisiecki, L. E. and Raymo, M. E.: A Pliocene-Pleistocene stack of 57 globally distributed benthic delta O-18 records, Paleoceanography, 20, PA1003, doi:10.1029/2004pa001071, 2005.

Loulergue, L., Schilt, A., Spahni, R., Masson-Delmotte, V., Blunier, T., Lemieux, B., Barnola, J.-M., D. Raynaud, Stocker, T. F., and Chappellaz, J.: Orbital and millennial-scale features of atmospheric $\mathrm{CH}_{4}$ over the past 800000 years, Nature, 453, 383-386, doi:10.1038/nature06950, 2008.

Loutre, M. F., Fichefet, T., Goosse, H., Huybrechts, P., Goelzer, H., and Capron, E.: Factors controlling the last interglacial climate as simulated by LOVECLIM1.3, Clim. Past, 10, 1541-1565, doi:10.5194/cp-10-1541-2014, 2014.

Lunt, D. J., Abe-Ouchi, A., Bakker, P., Berger, A., Braconnot, P., Charbit, S., Fischer, N., Herold, N., Jungclaus, J. H., Khon, V. C., Krebs-Kanzow, U., Langebroek, P. M., Lohmann, G., Nisancioglu, K. H., Otto-Bliesner, B. L., Park, W., Pfeiffer, M., Phipps, S. J., Prange, M., Rachmayani, R., Renssen, H., Rosenbloom, N., Schneider, B., Stone, E. J., Takahashi, K., Wei, W., Yin, Q., and Zhang, Z. S.: A multi-model assessment of last interglacial temperatures, Clim. Past, 9, 699-717, doi:10.5194/cp-9-699-2013, 2013.

Mangerud, J., Astakhov, V., and Svendsen, J. I.: The extent of the Barents-Kara Ice Sheet during the Last Glacial Maximum, Quaternary Sci. Rev., 21, 111-119, doi:10.1016/s02773791(01)00088-9, 2002.

Marino, G., Rohling, E. J., Rodriguez-Sanz, L., Grant, K. M., Heslop, D., Roberts, A. P., Stanford, J. D., and Yu, J.: Bipolar seesaw control on last interglacial sea level, Nature, 522, 197-201, doi:10.1038/nature14499, 2015.

Masson-Delmotte, V., Buiron, D., Ekaykin, A., Frezzotti, M., Gallée, H., Jouzel, J., Krinner, G., Landais, A., Motoyama, H., Oerter, H., Pol, K., Pollard, D., Ritz, C., Schlosser, E., Sime, L. C., Sodemann, H., Stenni, B., Uemura, R., and Vimeux, F.: A comparison of the present and last interglacial periods in six Antarctic ice cores, Clim. Past, 7, 397-423, doi:10.5194/cp-7397-2011, 2011.

Masson-Delmotte, V., Schulz, M., Abe-Ouchi, A., Beer, J., Ganopolski, A., González Rouco, J., Jansen, E., Lambeck, K., Luterbacher, J., Naish, T., Osborn, T., Otto-Bliesner, B., T. Quinn, R. R., M. Rojas, X. S., and Timmermann, A.: Information from paleoclimate archives, in: Climate Change 2013: The Physical Science Basis, Contribution of Working Group I to the 
Fifth Assessment Report of the Intergovernmental Panel on Climate Change, edited by: Stocker, T. F., Qin, D., Plattner, G.-K., Tignor, M., Allen, S. K., Boschung, J., Nauels, A., Xia, Y., Bex, V., and Midgley, P. M., Cambridge University Press, Cambridge, United Kingdom and New York, NY, USA, 383-464, 2013.

Mayewski, P., Denton, G., and Hughes, T.: Late Wisconsin Ice Sheets in North America, in: The Last Great Ice Sheets, edited by: Denton, G. and Hughes, T., Wiley Interscience, New York, 67-178, 1981.

Mengel, M. and Levermann, A.: Ice plug prevents irreversible discharge from East Antarctica, Nature Climate Change, 4, 451455, doi:10.1038/nclimate2226, 2014.

Menviel, L., Timmermann, A., Timm, O. E., and Mouchet, A.: Deconstructing the Last Glacial termination: the role of millennial and orbital-scale forcings, Quaternary Sci. Rev., 30, 1155-1172, doi:10.1016/j.quascirev.2011.02.005, 2011.

Merz, N., Born, A., Raible, C. C., Fischer, H., and Stocker, T. F.: Dependence of Eemian Greenland temperature reconstructions on the ice sheet topography, Clim. Past, 10, 1221-1238, doi:10.5194/cp-10-1221-2014, 2014.

NEEM community members: Eemian interglacial reconstructed from a Greenland folded ice core, Nature, 493, 489-494, doi:10.1038/nature11789, 2013.

Obrochta, S. P., Crowley, T. J., Channell, J. E. T., Hodell, D. A., Baker, P. A., Seki, A., and Yokoyama, Y.: Climate variability and ice-sheet dynamics during the last three glaciations, Earth Planet. Sc. Lett., 406, 198-212, doi:10.1016/j.eps1.2014.09.004, 2014.

Oppo, D. W., McManus, J. F., and Cullen, J. L.: Evolution and demise of the Last Interglacial warmth in the subpolar North Atlantic, Quaternary Sci. Rev., 25, 3268-3277, doi:10.1016/j.quascirev.2006.07.006, 2006.

Opsteegh, J. D., Haarsma, R. J., Selten, F. M., and Kattenberg, A.: ECBILT: a dynamic alternative to mixed boundary conditions in ocean models, Tellus, 50, 348-367, doi:10.1034/j.16000870.1998.t01-1-00007.x, 1998.

Pépin, L., Raynaud, D., Barnola, J. M., and Loutre, M. F.: Hemispheric roles of climate forcings during glacial-interglacial transitions as deduced from the Vostok record and LLN-2D model experiments, J. Geophys. Res.-Atmos., 106, 3188531892, doi:10.1029/2001jd900117, 2001

Petit, J.-R., Jouzel, J., Raynaud, D., Barkov, N. I., Barnola, J.-M., Basile, I., Bender, M., Chappellaz, J., Davis, M. E., Delaygue, G., Delmotte, M., Kotlyakov, V. M., Legrand, M., Lipenkov, V. Y., Lorius, C., Pepin, L., Ritz, C., Saltzman, E., and Stievenard, M.: Climate and atmospheric history of the past 420000 years from the Vostok ice core, Antarctica, Nature, 399, 429436, doi:10.1038/20859, 1999.

Raynaud, D., Barnola, J. M., Souchez, R., Lorrain, R., Petit, J. R., Duval, P., and Lipenkov, V. Y.: Palaeoclimatology The record for marine isotopic stage 11, Nature, 436, 39-40, doi:10.1038/43639b, 2005.

Robinson, A., Calov, R., and Ganopolski, A.: Greenland ice sheet model parameters constrained using simulations of the Eemian Interglacial, Clim. Past, 7, 381-396, doi:10.5194/cp-7-381-2011, 2011.

Sánchez Goñi, M. F., Bakker, P., Desprat, S., Carlson, A. E., Van Meerbeeck, C. J., Peyron, O., Naughton, F., Fletcher, W. J., Eynaud, F., Rossignol, L., and Renssen, H.: European climate opti- mum and enhanced Greenland melt during the Last Interglacial, Geology, 40, 627-630, doi:10.1130/G32908.1, 2012.

Sjolte, J. and Hoffmann, G.: Modelling stable water isotopes in monsoon precipitation during the previous interglacial, Quaternary Sci. Rev., 85, 119-135, doi:10.1016/j.quascirev.2013.12.006, 2014.

Spahni, R., Chappellaz, J., Stocker, T. F., Loulerge, L., Hausammann, G., Kawamura, K., Flückiger, J., Schwander, J., Raynaud, D., Masson-Delmotte, V., and Jouzel, J.: Atmospheric methane and nitrous oxide of the late Pleistocene from Antarctic ice cores, Science, 310, 1317-1321, doi:10.1126/science.1120132, 2005.

Steen-Larsen, H. C., Masson-Delmotte, V., Hirabayashi, M., Winkler, R., Satow, K., Prié, F., Bayou, N., Brun, E., Cuffey, K. M., Dahl-Jensen, D., Dumont, M., Guillevic, M., Kipfstuhl, S., Landais, A., Popp, T., Risi, C., Steffen, K., Stenni, B., and Sveinbjörnsdottír, A. E.: What controls the isotopic composition of Greenland surface snow?, Clim. Past, 10, 377-392, doi:10.5194/cp-10-377-2014, 2014.

Stocker, T. F.: The Seesaw Effect, Science, 282, 61-62, doi:10.1126/science.282.5386.61, 1998.

Stocker, T. F. and Johnsen, S. J.: A minimum thermodynamic model for the bipolar seesaw, Paleoceanography, 18, 1087, doi:10.1029/2003PA000920, 2003.

Stone, E. J., Lunt, D. J., Annan, J. D., and Hargreaves, J. C.: Quantification of the Greenland ice sheet contribution to Last Interglacial sea level rise, Clim. Past, 9, 621-639, doi:10.5194/cp-9621-2013, 2013.

Stuiver, M., Reimer, P. J., Bard, E., Beck, J. W., Burr, G. S., Hughen, K. A., Kromer, B., McCormac, G., van der Plicht, J., and Spurk, M.: INTCAL98 radiocarbon age calibration, 24000-0 cal BP, Radiocarbon, 40, 1041-1083, 1998.

Svendsen, J. I., Astakhov, V. I., Bolshiyanov, D. Y., Demidov, I., Dowdeswell, J. A., Gataullin, V., Hjort, C., Hubberten, H. W., Larsen, E., Mangerud, J., Melles, M., Möller, P., Saarnisto, M., and Siegert, M. J.: Maximum extent of the Eurasian ice sheets in the Barents and Kara Sea region during the Weichselian, Boreas, 28, 234-242, doi:10.1111/j.1502-3885.1999.tb00217.x, 1999.

Svendsen, J. I., Alexanderson, H., Astakhov, V. I., Demidov, I., Dowdeswell, J. A., Funder, S., Gataullin, V., Henriksen, M., Hjort, C., Houmark-Nielsen, M., Hubberten, H. W., Ingolfsson, O., Jakobsson, M., Kjær, K. H., Larsen, E., Lokrantz, H., Lunkka, J. P., Lyså, A., Mangerud, J., Matiouchkov, A., Murray, A., Möller, P., Niessen, F., Nikolskaya, O., Polyak, L., Saarnisto, M., Siegert, C., Siegert, M. J., Spielhagen, R., and Stein, R.: Late Quaternary ice sheet history of northern Eurasia, Quaternary Sci. Rev., 23, 1229-1271, doi:10.1016/j.quascirev.2003.12.008, 2004.

Swingedouw, D., Fichefet, T., Huybrechts, P., Goosse, H., Driesschaert, E., and Loutre, M. F.: Antarctic ice-sheet melting provides negative feedbacks on future climate warming, Geophys. Res. Lett., 35, L17705, doi:10.1029/2008GL034410, 2008.

Turney, C. S. M. and Jones, R. T.: Does the Agulhas Current amplify global temperatures during super-interglacials?, J. Quaternary Sci., 25, 839-843, doi:10.1002/jqs.1423, 2010.

van de Berg, W. J., van den Broeke, M. R., van Meijgaard, E., and Kaspar, F.: Importance of precipitation seasonality for the interpretation of Eemian ice core isotope records from Greenland, Clim. Past, 9, 1589-1600, doi:10.5194/cp-9-1589-2013, 2013. 
Zweck, C. and Huybrechts, P.: Modeling the marine extent of northern hemisphere ice sheets during the last glacial cycle, Ann. Glaciol., 37, 173-180, doi:10.3189/172756403781815870, 2003.
Zweck, C. and Huybrechts, P.: Modeling of the northern hemisphere ice sheets during the last glacial cycle and glaciological sensitivity, J. Geophys. Res, 110, D07103, doi:10.1029/2004JD005489, 2005. 